\title{
DIAGNOSTIC UTILITY OF VARIOUS TECHNIQUES IN BODY FLUID CYTOLOGY- A COMPARISON BETWEEN ORDINARY CENTRIFUGE, CYTOCENTRIFUGE AND CELL BLOCK TECHNIQUES
}

\author{
Anjali Sonkar1, Puneet Tandon²
}

${ }_{13}^{\text {rd }}$ Year Resident, Department of Pathology, Gandhi Medical College, Bhopal, Madhya Pradesh. 2Pathology Specialist, Department of Pathology, Gandhi Medical College, Bhopal, Madhya Pradesh.

\section{ABSTRACT}

\section{BACKGROUND}

Cytological examination of serous effusions has been done for nearly a century and it has helped in staging and prognosis of the malignant tumours and also gave information regarding various inflammatory lesions of serous membranes.

\section{MATERIALS AND METHODS}

This study was a Descriptive study. The body effusions include peritoneal, pleural and pericardial fluids received in cytology section of Department of Pathology, Gandhi Medical College, Bhopal from 1st January 2017 to 31st May 2017. Conventional smears and Cytocentrifuge smears were prepared from each sample. Remaining fluid was processed histopathologically for preparation of cell block.

\section{RESULTS}

Out of total 85 effusion fluids, 42 cases were suspected/ diagnosed for malignancy with body effusions. Out of 42 cases, ordinary centrifuge detected $10(23.8 \%)$ samples as positive for malignancy and cell block has detected $36(85.7 \%)$ cases positive for malignant cells, whereas cytocentrifuge has detected $30(71.4 \%)$ cases positive for malignancy and $6(14.3 \%)$ cases suspicious for presence of malignant cells.

\section{CONCLUSION}

In our study, we have concluded that cell block and cytocentrifuge techniques are superior in detecting malignant cells in effusion fluids compared to ordinary centrifuge. Cell block also gives advantage of performing ancillary techniques for further study.

\section{KEYWORDS}

Cytocentrifuge, Cell Block, Effusion Cytology, Malignancy.

HOW TO CITE THIS ARTICLE: Sonkar A, Tandon P. Diagnostic utility of various techniques in body fluid cytology- a comparison between ordinary centrifuge, cytocentrifuge and cell block techniques. J. Evolution Med. Dent. Sci. 2018;7(10):1199-1203, DOI: $10.14260 /$ jemds/2018/274

\section{BACKGROUND}

This century is a century that is struggling with cancer and is continuing. In this struggle along with effective treatment methods, developing early and easy diagnostic techniques are crucial.(1) Cytological examination of serous effusions have been done for nearly a century in the diagnosis of malignancy and eventually in the detection of primary lesions.

It has helped for staging and prognosis of the malignant tumours and also gave information regarding various inflammatory lesions of serous membranes.(2) A positive diagnosis, especially for malignant cells, is always taken as definitive diagnosis and assists the clinicians in deciding the further course of action and treatment of the patient. It is a relatively simple and non-invasive technique, which helps in coming to a conclusion about aetiology of effusion as inflammatory, benign or malignant.(3)

Most of the laboratories perform direct smear prepared from centrifuged deposits of effusion. At times, lack of morphological details of the representative cells contribute

'Financial or Other Competing Interest': None.

Submission 08-02-2018, Peer Review 20-02-2018,

Acceptance 23-02-2018, Published 05-03-2018.

Corresponding Author:

Dr. Puneet Tandon,

E1/179, Arera Colony,

Bhopal-462016,

Madhya Pradesh.

E-mail: drpuneettandon@yahoo.co.in

DOI: $10.14260 /$ jemds $/ 2018 / 274$ conventional smears. (4)

Except in a few institutes, there is no standard technique for processing these fluids that is reliable and cost effective. The technique still widely used in most cytology laboratory of India is the centrifugation and sedimentation smear preparation technique. With use of ordinary centrifuge alone, collecting cells in scantily cellular samples is quite difficult resulting in more of unsatisfactory smears. Thus resulting in effusion being reported as negative or atypical without definitive diagnosis and false negative diagnosis. (5)

The aims and objective of our study was to compare morphological features of the conventional smear method with those of cytocentrifuge and cell block techniques. Also to assess the utility and sensitivity of cytocentrifuge and cell block methods in cytodiagnosis of effusion.

\section{MATERIALS AND METHODS}

The body effusions include peritoneal, pleural and pericardial fluids received in cytology section of Department of Pathology, Gandhi Medical College, Bhopal from 1st January 2016 to 31st May 2017 were selected. Conventional smears and cytocentrifuge smears were prepared from each samples. Remaining fluid were processed histopathologically for preparation of cell block.

\section{Study Design}

Descriptive study. 


\section{Sample Size}

All fluid samples received in cytology section in Department of Pathology, Gandhi Medical College, Bhopal were included.

\section{Inclusion Criteria}

All fluid samples from pleural, peritoneal and pericardial effusion were included.

\section{Exclusion Criteria}

- Grossly contaminated samples.

- Inadequate samples (Volume $<15 \mathrm{~mL}$ ).

\section{Procedure}

All the fluids (pleural, peritoneal and pericardial) sent for cytological analysis in cytology section of Department of Pathology were received with proper labelling of samples along with requisition form filled with all clinical details.

Proper labelling of sample include fluid sent in sterile container with name of patient, age, sex, ward, fluid (pleural, peritoneal and pericardial) for cytology.

Along with this patient's clinical detail should be obtained which include provisional diagnosis, presenting complaints, relevant past history, family history and treatment history.

This is necessary for clinico-pathological correlation of diagnosis.

\section{All the Samples should be examined for its Physical} Characteristics which include-

- Volume (>15 mL).

- Colour.

- Transparency.

- Presence of blood/clot.

- Gross contamination.

After examining fluids for its physical characteristics, each sample was divided in three parts with minimum of 5 $\mathrm{mL}$ in each part.

One part of sample is subjected for routine centrifuge practiced in our cytology section, centrifuged at $1500 \mathrm{rpm}$ for 15 mins and smears prepared from sediment obtained in albumin coated slides.

Other part was subjected to cytocentrifuge, i.e. 300 microlitre of fluid was placed in cytocentrifuge funnel with the filter paper placed between the slide and the funnel, then subjected to centrifugation at $700 \mathrm{rpm}$ for 6 minutes. Smears were prepared from this part in similar way.

Two slides were prepared from each of the abovementioned technique (i.e. ordinary centrifuge and cytocentrifuge), one subjected for $\mathrm{H}$ and $\mathrm{E}$ staining and other for PAP staining.

The slides were then fixed in 95\% ethanol for 15 minutes and stained with haematoxylin and eosin as well as Pap stain.

Now the remaining third part of the sample is taken for cell block technique. The third part of the fluid was fixed in $10 \%$ formal alcohol in the ratio of 1: 1 and kept for 1 hour. After fixation it was centrifuged at $2000 \mathrm{rpm}$ for 10 minutes.

The supernatant was poured off and the cell button formed was obtained on Whatman filter paper number 1 . The sediment was wrapped in the same filter paper and processed in histokinette and embedded in paraffin. Sections were cut at 5 micro $\mathrm{m}$ and stained with haematoxylin and eosin.
In order to standardise the present study, Mair et al scoring system(6) was utilised.

In this Scoring System, Smears Obtained by all Three Techniques under Study are evaluated for the following Features-

a. Background- for presence of blood or proteinaceous material.

b. Amount of cellularity.

c. Cellular morphology and cell degeneration.

d. Distribution of cells.

\begin{tabular}{|c|c|c|c|}
\hline Score & $\mathbf{0}$ & 1 & 2 \\
\hline $\begin{array}{l}\text { Background- } \\
\text { blood or } \\
\text { proteinaceous }\end{array}$ & $\begin{array}{l}\text { Large amount, } \\
\text { great } \\
\text { compromise in } \\
\text { diagnosis }\end{array}$ & $\begin{array}{l}\text { Moderate } \\
\text { amount, } \\
\text { diagnosis } \\
\text { possible }\end{array}$ & $\begin{array}{c}\text { Minimal, } \\
\text { diagnosis } \\
\text { easy }\end{array}$ \\
\hline $\begin{array}{l}\text { Amount of } \\
\text { cellularity }\end{array}$ & $\begin{array}{l}\text { Minimal to } \\
\text { absent, } \\
\text { diagnosis not } \\
\text { possible }\end{array}$ & $\begin{array}{l}\text { Sufficient for } \\
\text { cytodiagnosis }\end{array}$ & $\begin{array}{c}\text { Abundant, } \\
\text { diagnosis } \\
\text { simple }\end{array}$ \\
\hline $\begin{array}{c}\text { Cell } \\
\text { morphology/ } \\
\text { degeneration }\end{array}$ & $\begin{array}{l}\text { Marked cell } \\
\text { degeneration, } \\
\text { diagnosis not } \\
\text { possible }\end{array}$ & $\begin{array}{c}\text { Moderate cell } \\
\text { degeneration, } \\
\text { diagnosis } \\
\text { possible }\end{array}$ & $\begin{array}{c}\text { Minimal } \\
\text { cellular } \\
\text { degeneration } \\
\text { diagnosis } \\
\text { easy }\end{array}$ \\
\hline $\begin{array}{l}\text { Distribution } \\
\text { of cells }\end{array}$ & $\begin{array}{c}\text { Sparsely } \\
\text { distributed }\end{array}$ & Combination & $\begin{array}{c}\text { Evenly } \\
\text { distributed }\end{array}$ \\
\hline \multicolumn{4}{|c|}{ Table 1. Mair et al Scoring System } \\
\hline
\end{tabular}

Depending on the Total Score obtained for each Feature Studied in every Smears obtained by all the Three Techniques, Smears are Categorised for its Adequacy as Following(6)

1. Diagnostically superior- total score 6-8.

2. Diagnostically adequate- total score 3-5.

3. Diagnostically inadequate- total score $<3$.

Data was analysed using SPSS version 16. The qualitative data were expressed as numbers and percentages.

\section{RESULTS}

The duration of study was from January 2016 to May 2017, during which total of 572 body fluids were received for cytological analysis.

Out of 572 fluids include 108 synovial fluids, 150 were bronchial washings and Bronchoalveolar lavage fluid (BAL), 50 were sputum for cytological examinations and 50 were ovarian cyst fluid.

In remaining 214 specimens which included peritoneal, pleural and pericardial fluids, only 85 samples could be processed for all three techniques simultaneously (ordinary centrifuge, cytocentrifuge and cell block technique), after examining each sample for its adequacy.

Out of 85 samples, 57 samples were peritoneal fluids, 25 samples were pleural fluids and 3 cases were of pericardial effusion. 


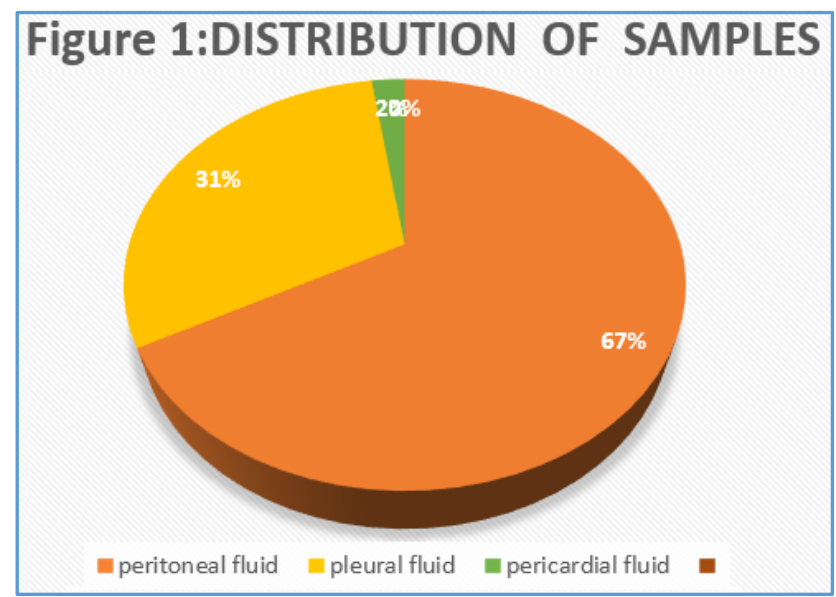

Out of total of 85 samples, $56(65.9 \%)$ samples were from female and 29 (34.1\%) samples were from male patients.

We got maximum number of cases for cytological analysis, which comprises age group of 17 to 85 years with mean age of 50 years and standard deviation of 18.226 .

Most of the patients who were females presented with complaints of ovarian neoplasm with ascites (23 cases), whereas most of male patients presented with pulmonary tuberculosis associated with pleural effusion (09 cases).

\section{Physical Appearance of Effusion Samples}

Most of the ascitic fluid included in study were pale yellow, clear fluid (30 cases).

On the other hand, most of pleural fluids were grossly haemorrhagic (18 cases), which were processed further after addition of $2 \%$ glacial acetic acid. Glacial acetic acid lyses all the red blood cells leaving other cells behind in the fluid unaltered. Pericardial fluids received were only two, comprising $2.4 \%$ of all samples.

\section{DISCUSSION}

Smears prepared from all three techniques, for each sample, were analysed using Mair et al scoring system.

a. Ordinary centrifuge shows large amount of background material in smears in about $37.6 \%$ of cases, where definite diagnosis is difficult to make. About $61.2 \%$ cases shows moderate background material making smears sufficient for diagnosis. In both cases, probability of missing malignant cells in smear is high. Minimal background material is present in $1.2 \%$ of cases where diagnosis is easy to be made. With cytocentrifuge, diagnostic adequacy improves in terms of background material. Only $3.5 \%$ of cases shows large background material, where diagnosis is difficult. About $70.6 \%$ of cases shows moderate background material in smears, where diagnosis can be made. About $25.6 \%$ of cases shows diagnostic superiority with cytocentrifuge method. With cell block technique, diagnostic adequacy improves markedly. $76.5 \%$ cases show minimal background material, so diagnosis can be given easily. $21.1 \%$ cases show moderate background material, which is sufficient for diagnosis. Only $2.4 \%$ of cases show large background material in smears.

b. With ordinary centrifuge, diagnostic adequacy of smears based on cellularity shows $62.4 \%$ of smears showing minimal cellularity (Diagnostically inadequate), $35.3 \%$ of smears show moderate cellularity (diagnostically adequate) and only $2.4 \%$ of smears shows abundant cellularity (diagnostically superior). With cytocentrifuge $75.3 \%$ of smears show moderate cellularity (diagnostically adequate), $21.1 \%$ of cases shows abundant cellularity (diagnostically superior) and only $3.5 \%$ of cases showing minimal cellularity (diagnostically inadequate). With cell block technique diagnostic adequacy increases markedly in terms of cellularity as well. About $63.5 \%$ of cases showing abundant cellularity (diagnostically superior), $35.3 \%$ of smears are diagnostically adequate showing moderate cellularity. Only $1.2 \%$ of cases shows minimal cellularity (Diagnostically inadequate) with cell block method.

c. Ordinary centrifuge shows $41.2 \%$ (Diagnostically inadequate) of smears having abundant cell degeneration, where diagnosis is difficult to be made. About $56.5 \%$ of smears showing moderate cell degeneration (Diagnostically adequate) and only $2.4 \%$ (Diagnostically superior) cases showing minimal cell degeneration where diagnosis is easy to be made. With cytocentrifuge, $74.1 \%$ of cases showing moderate cell degeneration (Diagnostically adequate), which is sufficient for making diagnosis. About $24.7 \%$ of smears are showing minimal cell degeneration (Diagnostically superior), where diagnosis is easy to be made. Only $1.2 \%$ of smears are showing abundant cell degeneration, so that diagnosis is difficult to be made. With cell block technique, $56.4 \%$ of smears showing minimal cell degeneration (Diagnostically superior) where diagnosis is easy to be made. $41.2 \%$ of smears showing moderate cell degeneration (Diagnostically adequate), which are sufficient for making diagnosis. Only $2.4 \%$ of smears are showing abundant cell degeneration (Diagnostically inadequate), where diagnosis cannot be made out.

d. With ordinary centrifuge, $56.5 \%$ of smears are showing sparse distribution of cells (Diagnostically inadequate) where diagnosis is difficult to be made. $40 \%$ of smears are showing sparse as well as even distribution of cells in smear (Diagnostically adequate), where diagnosis can be given. $3.5 \%$ of cases showing even distribution of cells (Diagnostically superior) throughout the smear, where diagnosis is easy to be made. With cytocentrifuge 3.5\% of smears are showing sparsely distributed cells (Diagnostically inadequate) in smears, so that diagnosis is difficult to be made. $75.3 \%$ of cases are showing sparse as well as even distribution of cells in smears (Diagnostically adequate), which is sufficient for diagnosis. $21.2 \%$ of smears are showing even distribution of cells (Diagnostically superior), where diagnosis is easily given. With cell block method, $72.9 \%$ of smears are diagnostically superior showing even distribution of cells where it is easy to make diagnosis. $24.7 \%$ of cases are showing sparse as well as even distribution of cells (Diagnostically adequate). $2.4 \%$ of cases shows sparsely distributed cells throughout the smears (Diagnostically inadequate). 


\begin{tabular}{|c|c|c|c|c|c|c|}
\hline Total Score & $\begin{array}{c}\text { No. of Cases Ordinary } \\
\text { Centrifuge }\end{array}$ & $\begin{array}{l}\text { Percent Ordinary } \\
\text { Centrifuge }\end{array}$ & $\begin{array}{l}\text { No. of Cases } \\
\text { Cytocentrifuge }\end{array}$ & $\begin{array}{c}\text { Percent } \\
\text { Cytocentrifuge }\end{array}$ & $\begin{array}{c}\text { No. of } \\
\text { Cases } \\
\text { Cell Block } \\
\end{array}$ & $\begin{array}{c}\text { Percent } \\
\text { Cell } \\
\text { Block } \\
\end{array}$ \\
\hline $\begin{array}{c}\text { Diagnostically } \\
\text { inadequate } \\
\text { (Total Score 0-3) }\end{array}$ & 80 & $94.1 \%$ & 7 & $8.2 \%$ & 02 & $2.7 \%$ \\
\hline $\begin{array}{c}\text { Diagnostically } \\
\text { adequate } \\
\text { (Total Score 4-5) }\end{array}$ & 03 & $3.5 \%$ & 56 & $65.9 \%$ & 05 & $5.9 \%$ \\
\hline $\begin{array}{l}\text { Diagnostically } \\
\text { superior } \\
\text { (Total Score 6-8) }\end{array}$ & 02 & $2.4 \%$ & 22 & $25.9 \%$ & 78 & $91.4 \%$ \\
\hline Total & 85 & $100 \%$ & 85 & $100 \%$ & 85 & $100 \%$ \\
\hline
\end{tabular}

Out of 42 suspected cases of malignancy presenting with body effusion and body fluid sent for malignant cytology with ordinary centrifuge only in 10 cases malignant cells were identified, whereas 32 cases were diagnosed as benign as no malignant cells were seen. With cytocentrifuge technique, out of 42 cases 30 cases shows presence of malignant cells with adequate cellular morphology. While 06 cases were suspicious of malignancy in cytocentrifuge, which were diagnosed as benign lesion in ordinary centrifuge and in cell block they were diagnosed definitively as malignancy. With cell block technique, results were similar to that of cytocentrifuge (36 cases out of 42 are showing malignant cell positivity). In smears of cell block, specific cellular architecture is appreciated which helps in identifying the primary malignancy.

Among 57 total cases of peritoneal fluids received for malignant cytology, 35 cases were clinically diagnosed as malignancy. Out of that 35 cases, 2 were diagnosed as reactive effusion in all three techniques. In ordinary centrifuge only 10 cases were diagnosed for malignancy, whereas 23 were suspected for malignant effusion. In cytocentrifuge technique, out of 23 suspected cases of malignancy, 13 were confirmed for presence of malignant cells whereas 10 were still suspicious for malignancy. In cell block method, all 33 cases were positive for malignancy.

Out of 26 total pleural fluids, 16 samples which were clinically diagnosed as tuberculosis/ lung consolidation shows chronic inflammation in all the three techniques. 7 cases which were clinically diagnosed as pneumonia shows acute inflammation in cytological techniques. For malignancy, out of remaining 3 samples 1 is showing reactive changes in all three techniques under study. 2 were suspicious for malignancy in ordinary centrifuge, which were confirmed by cell block and cytocentrifuge methods as malignant effusion.

Similarly, in pericardial fluid, one case comes out as positive for malignancy in cell block and cytocentrifuge technique which was missed by ordinary centrifuge method.

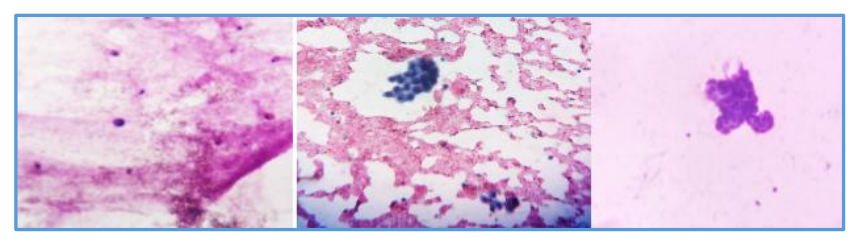

Figure 2. Smear from Ascitic Fluid from Case of Gall Bladder Mass showing Cluster of Hyperchromatic Malignant Cells in Effusion Fluid using Ordinary Centrifuge, Cytocentrifuge and Cell Block Technique

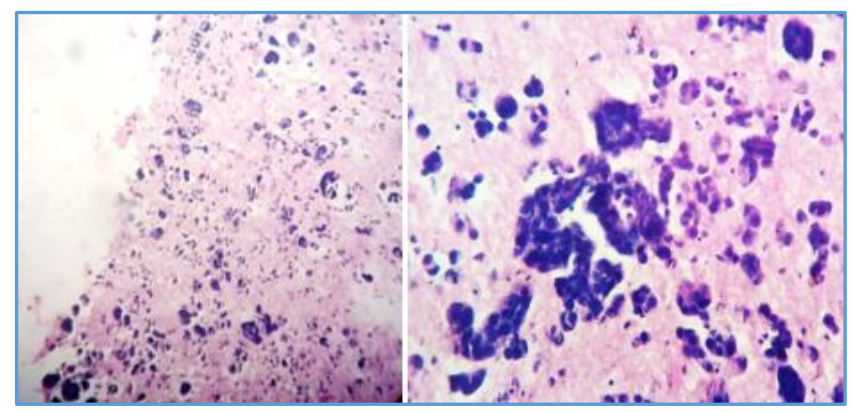

Figure 3. Cell Block Preparation from Case of Breast Carcinoma with Pleural Effusions show Tubular Arrangement of Pleomorphic Hyperchromatic Tumour Cells

\begin{tabular}{|c|c|}
\hline Authors & Sensitivity of Cell Block Technique \\
\hline Axe et al, 1986(7) & $73 \%$ \\
\hline $\begin{array}{c}\text { Kern and Haber, } \\
\text { 1986(8) }\end{array}$ & $60.0 \%$ \\
\hline $\begin{array}{c}\text { Wojcik and Selvaggi, } \\
\text { 1991( }{ }^{\prime}\end{array}$ & $84 \%$ \\
\hline $\begin{array}{c}\text { Leung and Bedard, } \\
\text { 1993(10) }\end{array}$ & $86 \%$ \\
\hline Nathan NA 2000 & $89.4 \%$ \\
\hline Present Study, 2017 & $97.2 \%$ \\
\hline Table 3. Showing Sensitivity of Cell Block Technique in \\
Various Studies \\
\hline
\end{tabular}

\section{CONCLUSION}

With use of cell block technique in study of body effusion for malignant cytology, we found the following results:

1. In terms of presence of background material (Presence of blood or proteinaceous material), smears from ordinary centrifuge shows large amount of background material obscuring cellular details and therefore diagnosis is very difficult to be made. With addition of cytocentrifuge and cell block methods background material is decreased significantly, and hence more definitive diagnosis can be made.

2. When observing for cellularity, cytocentrifuge gives better cellularity when compared with ordinary centrifuge. Cellularity is further enhanced when cell block smears are added with cytocentrifuge technique, thereby increasing sensitivity and specificity.

3. In terms of cell degeneration, more of cellular degeneration is observed with ordinary centrifuge method. Cell morphology is better preserved with cytocentrifuge and cell block method. 
4. With distribution of cells in smears, cell block shows better specific cellular arrangement with evenly distributed cells throughout the smears and hence it is easy to find out malignant cells in smears.

5. Cytocentrifuge though shows cellularity comparable to cell block, but it fails to show definite architecture of malignant cells and hence it is the most important advantage of cell block over cytocentrifuge.

6. Apart from all other cytomorphological advantages of cell block over conventional centrifuge and cytocentrifuge technique, it also offers use of ancillary techniques like immunohistochemistry, immunocytochemistry and molecular techniques.

\begin{tabular}{|c|c|c|c|}
\hline $\begin{array}{c}\text { Cytomorphologic } \\
\text { al } \\
\text { Features }\end{array}$ & $\begin{array}{c}\text { Ordinary } \\
\text { Centrifuge }\end{array}$ & $\begin{array}{c}\text { Cytocentrifug } \\
\text { e }\end{array}$ & Cell Block \\
\hline Background & \begin{tabular}{|c|} 
Inferior to \\
cytocentrifug \\
e and cell \\
block \\
\end{tabular} & $\begin{array}{l}\text { Superior to } \\
\text { ordinary } \\
\text { centrifuge }\end{array}$ & $\begin{array}{c}\text { Superior-to- } \\
\text { ordinary } \\
\text { centrifuge }\end{array}$ \\
\hline Cellularity & $\begin{array}{l}\text { Minimum } \\
\text { cellularity }\end{array}$ & $\begin{array}{l}\text { Minimum-to- } \\
\text { moderate } \\
\text { cellularity }\end{array}$ & $\begin{array}{c}\text { Moderate-to- } \\
\text { abundant } \\
\text { cellularity }\end{array}$ \\
\hline Cell degeneration & $\begin{array}{c}\text { Severe cell } \\
\text { degeneration }\end{array}$ & $\begin{array}{c}\text { Moderate-to- } \\
\text { minimal cell } \\
\text { degeneration }\end{array}$ & $\begin{array}{r}\text { Minimal cell } \\
\text { degeneration }\end{array}$ \\
\hline Distribution of cell & $\begin{array}{c}\text { Sparse } \\
\text { distribution }\end{array}$ & $\begin{array}{c}\text { Sparse-to- } \\
\text { even } \\
\text { distribution } \\
\end{array}$ & $\begin{array}{c}\text { Even } \\
\text { distribution } \\
\text { throughout }\end{array}$ \\
\hline Cell architecture & $\begin{array}{r}\text { Minima } \\
\text { apprecia }\end{array}$ & $\begin{array}{c}\text { Can be } \\
\text { appreciated }\end{array}$ & $\begin{array}{c}\text { Better } \\
\text { appreciated }\end{array}$ \\
\hline Nuclear details & $\begin{array}{c}\text { Less } \\
\text { appreciable }\end{array}$ & $\begin{array}{c}\text { More } \\
\text { appreciable } \\
\text { than ordinary } \\
\text { centrifuge }\end{array}$ & $\begin{array}{c}\text { Better } \\
\text { appreciable } \\
\text { than } \\
\text { cytocentrifug } \\
\text { e and } \\
\text { ordinary } \\
\text { centrifuge }\end{array}$ \\
\hline Ancillary test & $\begin{array}{l}\text { Cannot be } \\
\text { used }\end{array}$ & $\begin{array}{c}\text { Cannot be } \\
\text { used }\end{array}$ & $\begin{array}{l}\text { Can be used } \\
\text { for immuno- } \\
\text { cytochemistr } \\
\text { y as well as } \\
\text { molecular } \\
\text { techniques } \\
\end{array}$ \\
\hline codvont & & & sifa \\
\hline
\end{tabular}

Advantages of Cell Block Technique in Body Fluid Cytology

1. Recognition of histologic patterns of diseases that sometimes cannot be identified reliably in conventional smears.

2. Possible processing of the same material for routine histopathological staining, special staining and immunologic procedure.

3. Less cellular dispersion, which permits easier microscopic observation than do the conventional smears.

4. Less difficulty on overall microscopic observation.
5. Lower cost than the biopsies.

6. Possibilities of storing slides for retrospective studies. Storage of the conventional smear is a practical problem.

We were able to reach to conclusion that with cell block technique, preparation of diagnostically superior smears and cytomorphological features of malignant cells in smears of effusion samples which were better appreciable than smears from conventional techniques.

Thus, for helping in early diagnosis, better patient management and care by initiating correct treatment protocols as early as possible. We would recommend use of cell block techniques with conventional cytological methods of body fluid analysis.

\section{ACKNOWLEDGEMENTS}

I hereby like to thank Dr. Reeni Malik, Head of Department of Pathology, Gandhi Medical College, Bhopal and Dr. Puneet Tandon, Pathology Specialist, Class I, Department of Pathology, Gandhi Medical College, Bhopal for their valuable support in completing my research work. I would like to thank all team members and staff members of Department of Pathology, Gandhi Medical College, Bhopal for guiding me whenever I needed their support.

\section{REFERENCES}

[1] Ugurluoglu C, Kurtipek E, Unlu Y, et al. Importance of the cell block technique in diagnosing patients with non-small cell carcinoma accompanied by pleural effusion. Asian Pac J Cancer Prev 2015;16(7):3057-60.

[2] Joshi A, Mahajan N, Karmarkar PJ, et al. Diagnostic utility of various techniques used in body fluid cytology. IOSR-JDMS 2014;13:13-8.

[3] Suri J, Gandotra V, Abrol D, et al. Analysis of cell block vs. conventional smear in fluid cytology. Journal of Evidence Based Medicine and Healthcare 2015;2(39):6464-71.

[4] Priya PP. Cytological analysis of body fluids in conventional smear and cell block technique-study of 120 cases. Int J Pharm Bio Sci 2015;6(4):(B) 609-15.

[5] Mair S, Dunbar F, Becker PJ, et al. Fine needle cytology: is aspiration suction necessary? A study of 100 masses in various sites. Acta Cytol 1989;33(6):809-13.

[6] Thapar M, Mishra RK, Sharma A, et al. Critical analysis of cell block versus smear examination in effusions. J Cytol 2009;26(2):60-4.

[7] Axe SR, Erozan YS, Ermatinger SV. Fine-needle aspiration of the liver. A comparison of smear and rinse preparations in the detection of cancer. Am J Clin Pathol 1986;86(3):281-5.

[8] Kern WM, Haber M. Fine-needle aspiration minibiopsies. Acta Cytol 1986;30(4):403-8.

[9] Wojcik EM, Selvaggi SM. Comparison of smears and cell blocks in the fine-needle aspiration diagnosis of recurrent gynaecological malignancies. Acta Cytol 1991;35(6):773-6.

[10] Leung SW, Bedard YC. Simple miniblock technique for cytology. Mod Pathol 1993;6(5):630-2. 